\title{
Why Indonesian Universities Should Take Benefits from MOOC (Massive Open Online Course)
}

\author{
Beny $^{\mathrm{a}, 1}$, Ibnu Sani Wijaya ${ }^{\mathrm{a}, 2}$, Setiawan Assegaff ${ }^{\mathrm{a}, 3}$ \\ ${ }^{a}$ STIKOM Dinamika Bangsa, Jl. Jendral Soedirman, Jambi 36133, Indonesia \\ ${ }^{1}$ beny@stikom-db.ac.id, ${ }^{2}$ i13nu17@ @stikom-db.ac.id, ${ }^{3}$ setiawan@stikom-db.ac.id
}

\begin{abstract}
MOOC (Massive Open Online Course) gains its popularity in a couple of years. Top United States universities are racing to give their best courses under their best professors. While the Internet access in Indonesia is getting main stream, the chance to get top quality learning materials from famous University becomes easier. In this paper we discuss about MOOC (Massive Open Online Course) and how universities in Indonesia could take benefit from MOOC to give their students learning materials with international standard. This paper introduces the current situation of the growing popularity of MOOC (Massive Open Online Course). The system and technology behind MOOC and the benefits from adopting it will be also are analyzed. Based on this foundation, we propose strategy for Universities in Indonesia to take benefit from MOOC to increase the quality of their existing learning material.

Index Terms - MOOC, E-Learning, Indonesia, Higher Education.
\end{abstract}

\section{Introduction}

In 2012, some famous American universities and companies started providing online learning service known as MOOC, hence 2012 is known as the year of MOOC [1]. MOOC is an acronym of Massively Open Online Course [2], and the word 'massive' here can be proven by the number of the students who registered for the courses provided, more than 8 million registration has been recorded [3]. With the continuous development of MOOC, it can be defined from two points of view. In pedagogy point of view, MOOC can be described as an independent self-learning [4], in technology point of view, a MOOC is content-intensive, socially- and cognitively-embedded, cloud-based computing systems around which communities of content publishers and consumers assemble and interact [5].

Supporting technologies in MOOC are actually not new ground breaking invention. Generally a MOOC service runs on internet services which consists of video lectures, interactive problems, online laboratories, and discussion forum [6]. That is why anyone with decent Internet connection can take available courses.

With the popularity of the MOOC, some consider it as hype, and doubt it will replace traditional learning process, these various challenges will be discussed in section 3 . Considering MOOC is getting mature in recent years and the benefits provided by the system, some nations in the world and educational institutions are starting to accept MOOC as an alternative way for people to get higher education, this will be discussed in section 4 .

Enthusiastic students from developing countries are joining courses provided by MOOC services. This can be seen by the huge number of registrations [6]. And of course as a country with more than 4 million students currently pursuing bachelor degree [7], Indonesia should be able to take benefits from it. Universities and the government of Indonesia should have strategies in taking the most positive values of the MOOC and embrace it as a part of the educational processes. The strategies will be discussed in section 5.

\section{Current Situation of MOOC}

There are 3 major players who provide MOOC service; Coursera, edX, and Udacity. Each institution gets massive support from famous American universities and professors [8]. With decent Internet access, anyone from other countries can register and take a range of courses, which consists of various study fields, engineering field to language field [9]. Since anyone can participate in every course in MOOC, the number of registration is pretty high. High number in registration doesn't mean the number of student finished the course is high also. Only $4 \%$ course completion rate in some courses. Higher completion rate can be found in some courses with lower work load and homework [10].

Universities from outside America are starting to participate in providing lecture materials in MOOC. A course in Coursera taught by a lecturer from Hong Kong University of Science and Technology succeeded attract more than 17.000 students. The course was the first MOOC course from Asia. There is also signs of Chinese government working on its local content for MOOC's course [11].

Universities in Indonesia have not showed any activity in providing their own MOOC service. But private companies such as XL, known as cellular operator has its own MOOC service with one course about leadership [12]. And another private company Ciputra Group known for its business in property provides a free Entrepreneurship MOOC course taught by its own [13, 14].

\section{Challenges in MOOC}

MOOC is still trying to get its ideal form. With its existing platform, it is feared that MOOC's students will cheat without an effort, even though they will be asked to agree on the honor code. Students can access features such as discussion forum to discuss course materials and homework, and then again students are not allowed to give answers in the forum, but that will not stop people to create a black forum giving away answers for the quiz or homework problem. Furthermore, it is hard for bright students to stand out, thanks to the anonymity of the Internet. In addition, while it is an effortless job for computer to evaluate multiple 
choice or code assessment, it is still unfeasible for computer to evaluate assessments like essays [15].

As soon as MOOC will be used to get credits, beside cheating problem, there is a serious concern about how hard to monitor student identity, because a student who registers does not mean the same person who finish the course [16]. There is only small number of Universities (in America) that give credits score to students who successfully completed a MOOC course. The reason behind this circumstance is related to quality assurance of the materials given in the course. In some universities in America that give credit score based on MOOC's course completion are still struggling to interest its own students to get benefit from it [3].

In user participation perspective, MOOC is surprisingly attracts students who already have bachelor degree. This can be seen based on a study that shows $83 \%$ of 3000 surveyed MOOC users are scholar. While MOOC is intended to be used by more users from third world countries who wanted to taste American style education, $80 \%$ of MOOC users who come from countries like China, Brazil, South Africa, and India are already earned bachelor degree. One more thing to put in mind, there is approximately only $6 \%$ bachelor from total population of those countries mentioned earlier [17]. This means MOOC is still not doing good in reaching users who lives in poverty.

\section{Benefits and Opportunities in MOOC}

Regardless the challenges we discussed in previous section, MOOC is still considered to have great benefits and opportunities. MOOC could give the same impact to education like MP3 (Moving Picture Experts Group Layer-3 Audio) gave its impact to music industry [18]. Increasing number of MOOC services shows that we cannot stop its viral nature to spread, and it is unstoppable [4].

As we already mentioned earlier, MOOC services are free. Anyone can join available courses with only a decent Internet connection. People who can only dream to get access to American style higher education now can get it through MOOC without spending thousands of dollars [19]. With its gratis services, a study shows us that $85 \%$ professors who involved in MOOC believe that MOOC will lower down the cost of higher education [20].

The presents of MOOC services will make teachers or lectures in Universities to change their way of thinking in conducting their teaching method. A MOOC has tons of material contents which are impossible for a person creating it alone, and with its abundant contents, one will be able to give more variation in teaching and of course more quality in materials [21].

Universities can give credit score to students who completed a course in MOOC. To make it work, government can make a regulation for Universities to have legal base in giving credit score to their students. This kind of regulation is already produced by Florida and California. The law gives order to Universities in the state to make rules so their student to get credit scores from MOOC. [3].

\section{Strategies in Taking Benefits from MOOC}

As we discussed in previous section, there are concerns related to quality assurance of the courses given by a MOOC service. It will be difficult for an education institution to give credit score to students who completed a course taken in a MOOC service. This kind of situation needs an intervention from legal institution to determine which trustworthy MOOC service that can be partnered with universities in giving credit scores to students who finished its course.

The American Council on Education (ACE) chose several courses from Coursera and Udacity to give credit scores for universities in America. There are 2000 education institutions that refer to ACE recommendation, and these institutions can legally use the recommendation in giving credit score from the chosen MOOC services.

For institution that does not refer to ACE recommendation can implement a basic rule which requires a MOOC course should be taken and finished in an accredited institution, and the results will be evaluated by faculty in that institution [16]. Universities that follow ACE recommendation can give additional rules for students in getting credits from MOOC course. University of Maryland University College (UMUC) requires its students to show what they have learned by taking another final exam or doing final project to proof that they really understand what they have learned from MOOC's course [3].

Looking from teacher / lecturer point of view, one can implement a flipped class. Students will be assigned to access online teaching materials before attending the class, so as in the class the teacher can focus more on interactive session between student and teacher. Lecture videos given by famous American professors can be accessed whenever and wherever by the students. To make sure the students study the materials, a teacher can give them quiz to measure how far the students understand what they learned. This will enable a teacher to directly discuss the problem with the students in class. This method is already implemented by MIT, at least 10 traditional courses in MIT utilize edX platform for internal use, whether it uses flipped class as well as automatic evaluation for homework [24].

\section{Research Methodology}

This study is a literature review. The research finding was based on review and analysis from relevant articles in MOOCs topic. We collected articles from reputable database journal such as Google Scholar, EBSCOhost, ProQuest, IEEEexplore and Scopus. We used "MOOCs" and "Strategy" as a keyword. We did limit the article for ten years back. We found 40 papers and articles, and did review to the article abstracts. Finally, we selected 24 papers and articles. Twenty four relevant papers and articles then reviewed and analyzed. The analysis result is presented in section 2, 3, 4 and 5. This study also proposes a strategy on how to implement of MOOC in Indonesia higher Institution.

\section{Strategies for Universities in Indonesia}

In the mid of transition, Indonesia higher education needs to comprehend the phenomenon of MOOCs and make strategic decisions on how MOOCs to be adopted in their unique environment. 
In recent years, MOOC has emerged as promising solution for long life learning for massive participants. MOOCs can involve thousands of participants. The structure tends to be synchronous and flexible to accommodate varying level of participants. Anyone can participate freely in MOOCs learning activities [5].

Potential benefit of MOOCs in massive e-learning brings opportunities for Indonesia to adopt it as one solution in learning. Indonesia faces challenges by the geographic and demographic conditions that separate in huge area. Indonesia government needs to allocate numerous budgets in providing education institution physically. Unfortunately, Indonesian government still allocates the limited financial to cover all the expenses needed to build school facilities and in providing teaching staffs [22].

In 2003, Universitas Terbuka was the only university that is permitted to conduct e-learning in Indonesia. But, today the government has allowed some eligible institutions to carry out the e-learning [23]. Although some of eligible institutions are eligible to conduct e-learning, Indonesia is still facing some problems to adopt MOOCs, like regulation in the university related with acknowledgement of credit scores taken from a MOOC course. In many areas, access and connectivity are still limited and the computer literacy level of many people is still low, resulting in limited use of technology [22]. Indonesia is also facing difficulty in language (English) proficiency. Most of Indonesians are not familiar with English, as we know most of MOOCs contents are delivered in English.

In our opinion, there will be some strategies that can be applied by Indonesia government to fit all the needs of Indonesia Higher Institution Education and MOOCs.

1) A policy is needed to be established by the regulator (Government) to support E-learning implementation in Indonesia.

2) Universities in Indonesia should develop a mechanism and rules in how e-learning could become part of their legal educational system.

3) There are some options in using MOOCs as part of learning system in a university:

- Every course in MOOCs is equal with other regular course in the university

- MOOCs course can be offered as complement material to enrich already existing regular course.

- MOOCs course is one part of regular course

4) Government and Universities conduct a program to encourage lecturer develop MOOCs course contents.

This strategy could be considered as alternative solution to align universities mission and student requirement to have quality and various content from different e-learning sources. We belief implementation of MOOCs in Indonesia higher Institution would advance their services in learning system.

\section{Conclusion}

MOOCs system brings higher education institution opportunities to enhance their services to people with more easy and cheap. Although MOOCs is potential tools, in fact in some countries, especially in Indonesia, MOOCs is still not popular yet and has not been widely adopted. This study discussed related issues in MOOCs implementation and how it can be adopt in Indonesia higher education institution. Some previous studies related with MOOCs implementation was described along with the proposed strategy to implement in Indonesia.

\section{References}

[1] L. Pappano, "The Year of the MOOC," The New York Times, vol. 2, p. 2012, 2012.

[2] K. Masters, "A brief guide to understanding MOOCs," The Internet Journal of Medical Education, vol. 1, no. 2, 2011.

[3] S. Negrea, "Massive, open, online, for credit: three models for allowing students to earn credit for completed MOOCs," University Business, vol. 17, no. 3, 2014.

[4] J. Nyoni, "The viral nature of Massive Open Online Courses (MOOCs) in open and distance learning: discourses of quality, mediation and control," Mediterranean Journal of Social Sciences, vol. 4 , pp. 665,2013

[5] B. Dasarathy, K. Sullivan, D. C. Schmidt, D. H. Fisher, and A. Porter, "The past, present, and future of MOOCs and their relevance to software engineering," in Proceedings of the on Future of Software Engineering, pp. 212-224, 2014.

[6] L. Breslow, D. E. Pritchard, J. DeBoer, G. S. Stump, A. D. Ho, and D. Seaton, "Studying learning in the worldwide classroom: Research into edX's first MOOC," Research \& Practice in Assessment, vol. 8, pp. 13-25, 2013.

[7] Wan. (2012, 8 February). Tahun Depan Jumlah Mahasiswa Harus Naik 400 Ribu.

http://www.jpnn.com/read/2012/11/06/145983/Tahun-DepanJumlah-Mahasiswa-Harus-Naik-400-Ribu-

[8] N. B. Milman, "MOOCs: what are they? Plus 20 questions we should be asking about them " Distance Learning, vol. 9, p. 91, 2012.

[9] e. a. M. Elena, "Peer-to-peer interaction in Professional English MOOCs: A proposal for effective feedback," The European Conference on Language Learning 2013, 2013.

[10] "New study says MOOCs have few active users." Technology \& Learning, p. 10, 2014.

[11] Y. Sharma, "Hong Kong MOOC draws students from around the world," The Chronicle of Higher Education, 2013.

[12] (2014, 21 March). Indonesia's leadership e-curriculum. xlfutureleaders.com

[13] N. Wiji. (2013, 10 March). Mau belajar jadi pengusaha secara gratis ini caranya.

http://finance.detik.com/read/2013/08/25/103637/2339721/4/forum.d etik.com/mau-belajar-jadi-pengusaha-secara-gratis-ini-caranya

[14] B. Y. Maria. (2013, 1 February). Kuliah? Di UCEO Saja. http://news.bisnis.com/read/20130824/255/158567/kuliah-di-uceosaja

[15] D. Youngberg, "Why Online Education Won't Replace CollegeYet," The Chronicle of Higher Education, 2012.

[16] K. Domonell, "Managing MOOC Credits," University Business, vol. 16, 2013.

[17] D. Crystal, "Not Open To All," Diverse Issues in Higher Education, p. $9,2014$.

[18] C. Shirky, "Napster, Udacity, and the academy," Clay Shirky weblog.(November 12), 2012.

[19] D. Haynie, "5 Reasons international students should consider MOOCs," U.S. News \& World Report, p. 1, 2013.

[20] S. Kolowich, "The Professors behind the MOOC Hype," Chronicle of Higher Education, 2013.

[21] T. Bates, "What's right and what's wrong about Coursera-style MOOCs," ed, 2012.

[22] E. I. INDONESIA, "The historical context, current development, and future challenges of distance education in Indonesia," Quarterly Review of Distance Education, vol. 7, pp. 95-101, 2006.

[23] Z. A. Hasibuan and H. B. Santoso, "The use of e-learning towards new learning paradigm: Case study student centered e-learning environment at Faculty of Computer Science-University of Indonesia," ICALT 2005. Fifth IEEE International Conference on Advanced Learning Technologies, pp. 1026-1030, 2005

[24] Y. Jeffrey R., "Will MOOCs change campus teaching?" The Chronicle of Higher Education, 60.11. 2014. 